\title{
Differential Response of Biomass Production and Nitrogen Uptake of Vegetable Amaranth to Two Types of Poultry Manure from Nigeria and Canada
}

\author{
F. T. Olatoberu1, M. K. Idowu' ${ }^{1}$ J. A. Adepetu1 ${ }^{1}$, 0. O. Akinremi2 ${ }^{*}$ \\ ${ }^{1}$ Department of Soil Science and Land Resources Management, Faculty of Agriculture, Obafemi Awolowo University, Ile Ife, Nigeria \\ ${ }^{2}$ Department of Soil Science University of Manitoba, Manitoba, Canada \\ Email: *wole.akinremi@umanitoba.ca
}

How to cite this paper: Olatoberu, F.T., Idowu, M.K., Adepetu, J.A. and Akinremi, O.O. (2019) Differential Response of Biomass Production and Nitrogen Uptake of Vegetable Amaranth to Two Types of Poultry Manure from Nigeria and Canada. Food and Nutrition Sciences, 10, 694-711. https://doi.org/10.4236/fns.2019.106051

Received: November 13, 2018

Accepted: June 27, 2019

Published: June 30, 2019

Copyright $\odot 2019$ by author(s) and Scientific Research Publishing Inc. This work is licensed under the Creative Commons Attribution International License (CC BY 4.0).

http://creativecommons.org/licenses/by/4.0/

\begin{abstract}
Amaranthus cruentus is one of the sixty Amaranthus species of world. It is widely grown as a green leafy vegetable and for its grain in many tropical countries of Africa, Central and South American, Canada, Mexico and parts of Asia. Depleted soil fertility under intensive cultivation is a major limitation to production of the vegetable. The study investigated the effects of two types of poultry manure on biomass yield and nutrient uptake of Amaranth cruentus in a greenhouse at the University of Manitoba, Winnipeg, Manitoba, Canada in 2011. The experiment was a $2 \times 3 \times 3$ factorial arranged into a Randomized Completely Block Design and replicated three times. The factors were two soil types, two sources of poultry manure and urea, and $\mathrm{N}$ rates at 0 , 60 and $120 \mathrm{~kg} \cdot \mathrm{N} \cdot \mathrm{ha}{ }^{-1}$. Nitrogen uptake by the plants that treated with poultry manure from Canada (PMC) and Urea was 172.5 vs. $171.4 \mathrm{mg}^{-p^{-1}}{ }^{-1}$ and 169.5 vs. $163.7 \mathrm{mg} \cdot$ pot $^{-1}$ respectively which were significantly greater than the poultry manure from Nigeria (PMN), $100.6 \mathrm{mg} \cdot \mathrm{pot}^{-1}$ and $110.0 \mathrm{mg} \cdot \mathrm{pot}^{-1}$ for Red River and Glenhope soil series, respectively. Nitrogen uptake was similar at the $\mathrm{N}$ rates of 60 and $120 \mathrm{~kg} \cdot \mathrm{N} \cdot \mathrm{ha}^{-1}$ ( 140.7 vs. $155.6 \mathrm{mg} \cdot \mathrm{pot}^{-1}$ ) in the Red River soil, while $\mathrm{N}$ uptake at $120 \mathrm{~kg} \cdot \mathrm{N} \cdot \mathrm{ha}^{-1}$ was greater than at $60 \mathrm{~kg} \cdot \mathrm{N} \cdot \mathrm{ha}^{-1}$ in Glenhope soil. Shoot dry matter of the vegetable grown in soils treated with PMC and urea was significantly greater than from PMN in Red River soil

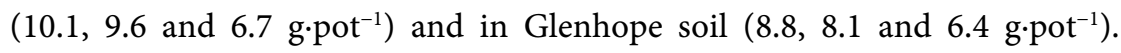
Phosphorus, $\mathrm{K}, \mathrm{Ca}$ and $\mathrm{Mg}$ uptake at 60 and $120 \mathrm{~kg} \cdot \mathrm{N} \cdot \mathrm{ha}{ }^{-1}$ were similar in the Red River soil whereas their uptake at $120 \mathrm{~kg} \cdot \mathrm{N} \cdot \mathrm{ha}^{-1}$ doubled the values obtained at $60 \mathrm{~kg} \cdot \mathrm{N} \cdot \mathrm{ha}^{-1}$ in Glenhope soil. The study concluded that interaction of source of fertilizers and application rate had no effect on nutrient uptake
\end{abstract}


and plant biomass yield, PMC contained higher nutrients compared with $\mathrm{PMN}$ and application of $60 \mathrm{~kg} \cdot \mathrm{N} \cdot \mathrm{ha}^{-1}$ was optimal for amaranth production.

\section{Keywords}

Amaranth, Poultry Manure, Urea, Soil Properties, Biomass Yield and Nutrients Uptake

\section{Introduction}

Despite the global reduction in the prevalence of undernourishment from 18.7 to 11.3 percent in 2012 to 2014 , more than 805 million people still do not have enough to eat [1]. Low agricultural production in the developing countries has been related to low soil fertility among other factors [2]-[7]. Agriculture in the developing countries in general and Nigeria in particular, requires substantial improvement if it is to contribute towards national food security, industrial growth and foreign exchange earnings [8]. Low soil nutrients have been established as a constraint under intensive cultivation. Soil organic matter content also decreased rapidly under tropical conditions [7] [9]. The use of fertilizers has been recognized as a way to overcome the challenge of low soil fertility [10] [11]. However, inorganic fertilizer is often unaffordable to resource-poor farmers [12] [13]. Therefore, the application of poultry manure as a source of nitrogen $(\mathrm{N})$, phosphorus $(\mathrm{P})$ and potassium $(\mathrm{K})$, and trace elements such as iron (Fe), copper $(\mathrm{Cu})$, and zinc $(\mathrm{Zn})$ has been suggested as a cost effective way of improving soil fertility [14] [15] [16] [17].

The nutrients in poultry litter exist in both mineral and organic forms, although released slowly [18]. Studies have shown that mineralisation of nutrients in manure takes up to seven weeks. The nutrient content of poultry manure is determined by the composition of poultry feed, drugs administered, type and age of the chicken and method of disposal of poultry manure [19]. However, in Nigeria, no methods are currently recommended for processing poultry manure or for determining its fertilizer equivalence. Information on the quality and availability of nutrients from soil-applied poultry manure is inconsistent. For instance, [20] reported that the application of poultry manure to the soil where maize was grown significantly increased N, P, Ca and some micronutrients concentration in the maize grains while [11] observed that inappropriate application of poultry manure to soil could damage plant root and sometime even kill plants.

The application of poultry manure to soils cultivated with vegetable crops is increasing due to increasing demand for organically produced vegetable crops in Africa in general, and Nigeria in particular. The ability of poultry manure to release nutrients, particularly nitrogen, to the crop has not been evaluated for short duration crops such as leafy vegetables. It is also unknown if the formula for estimating available nitrogen that has been used for manures in the temperate regions [21] will be appropriate for poultry manure from the tropics. 
Leafy vegetables are part of daily diets in many African and Nigerian households. The leave of amaranth constitutes an inexpensive and rich source of protein, carotenoid, vitamin C, and dietary fibre. Many vitamins are found in high level in both raw and cooked leaves and stems of Amaranthus cruentus such as vitamin $\mathrm{A}$, vitamin $\mathrm{C}$, riboflavin (vitamin B12) vitamin B6, folate (vitamin B9) and niacin (vitamin B3) [22]. Amaranthus is also rich in essential minerals such as iron, calcium, magnesium, phosphorus, potassium, zinc, copper and magnesium. It is also a very good source of protein with digestibility approximately $90 \%$ and are high in lysine; $0.74 \%$ Lys $/ 100 \mathrm{~g}$ of the edible portion of uncooked amaranth grain and is gluten-free [23]. Amaranth is being grown with increasing success in Canada and work is being done at both the University of Guelph's Sinicoe (leaf amaranth) and Vineland Research Stations (grain amaranth) [23]. They supply the body with minerals, vitamins and certain hormone precursors in addition to proteins and energy [24] [25].

It is therefore important that these vegetables be adequately fertilized if they are going to be relied upon as a source of essential nutrients. However, it is increasingly becoming difficult to meet the fertilizer demands of crops, which demands for methods to promote nutrient use efficiency that varies by both crop and fertilizer source. Vegetable crops differ because they often require higher rates of fertility only for yield but also quality as those nutrients are required at specific growth stages so nitrogen that can be maintained in the root zone, available at those critical moments is really important and difficult to do because it is highly mobile in solution.

\section{Materials and Methods}

\subsection{Study Location}

Poultry manure sample was collected from laying birds at the Teaching and Research Farm of the Obafemi Awolowo University, Ile-Ife, Nigeria, which lies between longitudes $4^{\circ} 32^{\prime} \mathrm{E}$ and $4^{\circ} 40^{\prime} \mathrm{E}$, and latitudes $7^{\circ} 32^{\prime} \mathrm{N}$ and $7^{\circ} 33^{\prime} \mathrm{N}$. This poultry manure sample, (PMN) was freeze dried and kept in air tight container, quarantined and transported to the University of Manitoba, Canada. Poultry manure sample was also collected from the Department of Animal Science, University of Manitoba, Canada and freeze dried (PMC), which lies on Latitude $49.8075^{\circ} \mathrm{N}$ and Longitude $97.1366^{\circ} \mathrm{W}$. It was believed that poultry manure of Nigeria could be different from that of Canada in ability to supply nutrients due to differences in the livestock feeds, drugs, environment and management practices. The chickens were egg layers and under battery cage system, in the two locations.

\subsection{Soil Analysis}

Two surface soils $(0-15 \mathrm{~cm})$ were collected from fields near Winnipeg, Manitoba that has not received fertilizer within the past five years. The locations were Longitude 97.17W, Latitude 49.46N and Altitude $226 \mathrm{~m}$ for Red River soil and 
Longitude $96.88 \mathrm{~W}$, Latitude $49.28 \mathrm{~N}$ and Altitude $266 \mathrm{~m}$ for Glenhope. The Red River clay is classified as Gleyed Rego Black Chernozem/Gleyed Humic Vertisol and the Glenhope loamy sand as Gleyed Rego Black Chernozem [26]. The soil samples were air-dried, gently crushed and passed through a $2 \mathrm{~mm}$ sieve. The fraction that passed through a $2 \mathrm{~mm}$ sieve was subjected to both physical and chemical analysis. The water content of the soil at field capacity was determined as described by [27].

Available $\mathrm{P}$ was extracted using $\mathrm{NaHCO}_{3}$ as described by [28]. Phosphorus concentration in the extract was determined using a spectrophotometer (Ultralspec 3100 pro UV/Visible spectrophotometer). Ammonium nitrogen $\left(\mathrm{NH}_{4}^{+}-\mathrm{N}\right)$ and nitrate nitrogen $\left(\mathrm{NO}_{3}^{-}-\mathrm{N}\right)$ were extracted using $2 \mathrm{~N} \mathrm{KCl}$ as described by [29]. The extract was analysed for ammonium nitrogen $\left(\mathrm{NH}_{4}^{+}-\mathrm{N}\right)$ and nitrate nitrogen $\left(\mathrm{NO}_{3}-\mathrm{N}\right)$ using an auto analyser (Technicon autoanalyser II system: Technicon Ind. System Tarrytown, NY). The $\mathrm{pH}$ and Electrical conductivity of the soils were determined using $\mathrm{pH}$ meter and conductivity meter, respectively (Accument Research ARSO, Fisher Scientific. Soil Exchangeable Ca, K, Mg, and $\mathrm{Na}$ and cation exchange capacity were also extracted by $25 \mathrm{~mL}$ of $1 \mathrm{~N} \mathrm{NH}_{4} \mathrm{OAc}$ solution as described by [30] using vacuum pump (Fisher maxima dry oil free laboratory vacuum pump model 13-880-16). The first solution from the soil was analysed for exchangeable $\mathrm{Ca}, \mathrm{K}, \mathrm{Mg}$ and $\mathrm{Na}$ with Inductively Couple Plasma (ICPOES) (Varian Incorporation, Palo Alto, CA, USA). The remaining soil was leached with $\mathrm{NaCl}$ (to release the $\mathrm{NH}_{4}^{+}$) and analysed for CEC with auto analyser (Technicon autoanalyser II system: Technicon Ind. System Tarrytown, NY). Soil ammonium nitrogen $\left(\mathrm{NH}_{4}^{+}-\mathrm{N}\right)$, nitrate nitrogen $\left(\mathrm{NO}_{3}^{-}-\mathrm{N}\right)$, and available $\mathrm{P}$ were determined after harvesting of the plants using the methods stated above.

\subsection{Poultry Manure and Livestock Feed Processing and Analysis}

After freeze drying, the manure samples from Nigeria and Canada were ground using Oster Blender. $0.4 \mathrm{~g}$ of the manure sample was digested with digestion mixture according to [31] ( $350 \mathrm{~mL} \mathrm{H}_{2} \mathrm{O}_{2}, 0.42 \mathrm{~g}$ Se powder, $14 \mathrm{~g} \mathrm{Li}_{2} \mathrm{SO}_{4} \cdot \mathrm{H}_{2} \mathrm{O}, 420$ $\mathrm{mL}$ conc. $\mathrm{H}_{2} \mathrm{SO}_{4}$ ) using the wet oxidation method described by [32]. Also part of the poultry manure sample was extracted using $2 \mathrm{~N} \mathrm{KCl}$ as described by [29] to measure ammonium-nitrogen. The digested and extracted poultry manure samples were analysed for total nitrogen and ammonium nitrogen $\left(\mathrm{NH}_{4}-\mathrm{N}\right)$ respectively with autoanalyser (Techniconautoanalyser II system: Technicon Ind. System Tarrytown NY). Plant Available Nitrogen was calculated using the expression:Available $\mathrm{N}=\mathrm{NH}_{4}^{+}-\mathrm{N}+25 \%$ of Organic $\mathrm{N}$

Where Organic $\mathrm{N}=$ Total $\mathrm{N}-\mathrm{NH}_{4}^{+}-\mathrm{N}$ [33].

Phosphorus, $\mathrm{K}, \mathrm{Ca}, \mathrm{Mg}, \mathrm{Al}$, and $\mathrm{Na}$ of the manure samples were analysed using Inductively Couple Plasma, ICP-OES (Varian Incorporation, Palo Alto, CA, USA).

\subsection{Greenhouse Study}

The greenhouse experiment was a $2 \times 3 \times 3$ factorial in a Completely Random- 
ized Design consisting of two soil types, three sources of nitrogen: PMN, PMC and urea which were added at three rates of 0 (control), 60 and $120 \mathrm{~kg} \cdot \mathrm{N} \cdot \mathrm{ha}^{-1}$ (Table 1). The experiment was replicated three times, with a total of fifty-four experimental units. The amaranth (Amaranthus cruentus) seeds were obtained from Prairie Garden seeds in Humboldt, Saskachewan, Canada. The seed was pre-germinated in a growth chamber that was set at $25^{\circ} \mathrm{C}$ during the day and night, and the relative humidity of $60 \%$. Each pot was filled with $2 \mathrm{~kg}$ of treated soil. Three germinated seeds were transplanted into each pot on $28^{\text {th }}$ July, 2011. The greenhouse experiment was for a duration of 5 weeks. Basal phosphorus and potassium were applied as $\mathrm{NH}_{4} \mathrm{H}_{2} \mathrm{PO}_{4}$ and $\mathrm{KCl}$ ANALAR grades reagent at the rate of $40 \mathrm{~kg} \mathrm{P} \cdot \mathrm{ha}^{-1}$ and $30 \mathrm{~kg} \mathrm{~K} \cdot \mathrm{ha}^{-1}$, respectively. The germinated seeds were irrigated daily, early in the morning to $70 \%$ field moisture capacity of the soil.

\subsection{Data Collection}

Plant height was measured on a weekly basis using a meter stick. The numbers of leaves were also recorded each week. The plants were harvested five weeks after transplanting.

\subsection{Extraction and Analysis of Plant Tissue}

The plants were partitioned into shoots and roots, and fresh weight was determined. Plant samples were oven dried at $60^{\circ} \mathrm{C}$ until a constant weight was obtained and the dry weight was measured.

\subsection{Determination of Plant Nutrient Uptake}

Oven dried plant tissues were finely ground with a Plant tissue mill (Thomas Wiley Laboratory mill, Model 4) and digested using the wet oxidation method described by [32]. The digested plant samples were analysed for total nitrogen with an autoanalyser (Technicon autoanalyser II system: Technicon Ind. System Tarrytown, NY). Phosphorus, $\mathrm{K}, \mathrm{Ca}, \mathrm{Mg}, \mathrm{Na}, \mathrm{Cu}$ and $\mathrm{Fe}$ in the digested sample were determined using Industrial Couple Plasma ICP-OES (Varian Incorporation, Palo Alto, CA, USA). The nutrient concentration of each plant samples was multiplied by their dry matter yield to get the nutrients uptake using the expression:

Table 1. Quantity of poultry manure applied to the soils.

\begin{tabular}{|c|c|c|c|c|c|c|}
\hline \multirow{3}{*}{$\begin{array}{c}\text { Rates } \\
\mathrm{kg} \cdot \mathrm{N} \cdot \mathrm{ha}^{-1}\end{array}$} & \multicolumn{6}{|c|}{ Poultry manure } \\
\hline & \multicolumn{3}{|c|}{ Canada } & \multicolumn{3}{|c|}{ Nigeria } \\
\hline & $\mathrm{kg} \cdot \mathrm{ha}^{-1}$ & $g \cdot \operatorname{pot}^{-1}$ & $\mathrm{~N}$ mg.pot ${ }^{-1}$ & $\mathrm{~kg} \cdot \mathrm{N} \cdot \mathrm{ha}^{-1}$ & $\mathrm{~g} \cdot \mathrm{pot}^{-1}$ & $\mathrm{~N}$ mg pot ${ }^{-1}$ \\
\hline & \multicolumn{3}{|c|}{$2 \mathrm{~kg}$ soil } & \multicolumn{3}{|c|}{$2 \mathrm{~kg}$ soil } \\
\hline 60 & 2710 & 3 & 67 & 4225 & 4.7 & 67 \\
\hline 120 & 5420 & 6 & 133 & 8510 & 9.5 & 133 \\
\hline
\end{tabular}




$$
\text { Nutrient removal }\left(\frac{\mathrm{g}}{\text { pot }}\right)=\frac{\text { dry matter yield }(g) \times \text { concentration }(\%)}{100 \%}
$$

\subsection{Statistical Analysis}

The data obtained was subjected to a two-way Anova also with SAS (source of N and rate of N). Each soil was analyzed separately so as to avoid third order interaction that may be difficult to interpret. Differences in means were tested using The Duncan Multiple Range Test (DMTR) at 5\% level of probability with SAS [34].

\section{Results and Discussion}

\subsection{Soil Properties, Poultry Manure and Feed Nutrient Compositions}

The physical and chemical properties of the soils used for the greenhouse experiment are shown in Table 2. The textural classifications of the soils were clay and loamy sand for the Red River and Glenhope soils, respectively. The Electrical conductivity and cation exchangeable capacity (CEC) as well as other properties of the Red River soil were higher than that of the Glenhope soil. This could be due to the high clay content of the Red River soil with is large surface area [35]. Overall, the soil native nutrients such as N, P, K were not sufficient for the production of optimal vegetable yield which might have been due to differences in production system. The poultry manure from Nigeria had lower total $\mathrm{N}$ compared to poultry manure from Canada (Table 3 ). It is a common practice

Table 2. Properties of the soil used for the experiment.

\begin{tabular}{|c|c|c|}
\hline Properties & Red River soil & Glenhope soil \\
\hline $\mathrm{pH}$ & 7.6 & 7.8 \\
\hline $\mathrm{EC}\left(\mathrm{mS} \cdot \mathrm{m}^{-1}\right)$ & 501 & 254 \\
\hline $\mathrm{FMC}\left(\mathrm{g} \cdot \mathrm{g}^{-1}\right)$ & 25 & 17 \\
\hline $\mathrm{NO}_{3}^{-}-\mathrm{N} \quad\left(\mathrm{mg} \cdot \mathrm{kg}^{-1}\right)$ & 32 & 4 \\
\hline $\mathrm{NH}_{4}^{+}-\mathrm{N} \quad\left(\mathrm{mg} \cdot \mathrm{kg}^{-1}\right)$ & 8 & 8 \\
\hline Available $\mathrm{P}\left(\mathrm{mg} \cdot \mathrm{kg}^{-1}\right)$ & 32 & 13 \\
\hline Exchangeable $\mathrm{Ca}\left(\mathrm{cmol} \cdot \mathrm{kg}^{-1}\right)$ & 11.9 & 4.9 \\
\hline $\mathrm{Mg}\left(\mathrm{cmol} \cdot \mathrm{kg}^{-1}\right)$ & 4.4 & 1.2 \\
\hline $\mathrm{K}\left(\mathrm{cmol} \cdot \mathrm{kg}^{-1}\right)$ & 2 & 1 \\
\hline $\mathrm{Na}\left(\mathrm{cmol} \cdot \mathrm{kg}^{-1}\right)$ & 0.4 & 0.3 \\
\hline $\mathrm{CEC}\left(\mathrm{cmol} \cdot \mathrm{kg}^{-1}\right)$ & 46.8 & 19 \\
\hline Sand (\%) & 6 & 83 \\
\hline Silt" & 25 & 9 \\
\hline Clay" & 69 & 8 \\
\hline Textural class & Clay & Loamy sand \\
\hline
\end{tabular}


Table 3. Chemical composition of the poultry manures used for the experiment.

\begin{tabular}{ccc}
\hline \multirow{2}{*}{ Nutrients } & \multicolumn{2}{c}{ Composition (\%) } \\
\cline { 2 - 3 } & Manure sample from Canada & Manure sample from Nigeria \\
\hline \multirow{2}{*}{ Ammonium N } & 0.6 & 1.1 \\
Total N & 6.9 & 2.3 \\
P & 2.7 & 2.3 \\
K & 2.8 & 2.2 \\
Mg & 0.7 & 0.9 \\
Ca & 6.7 & 7.7 \\
Fe & 0.1 & 0.7 \\
Al & 0.2 & 0.2 \\
Poultry feed N & 2.5 & 2.0 \\
\hline
\end{tabular}

amongst poultry farmers in Nigeria to leave poultry manure with the chicken for weeks before it is disposed off. This practice would have resulted in manure decomposition and significant loss of $\mathrm{N}$ to the atmosphere. This could partly be the reason for the low content of $\mathrm{N}$ in the PMN. Whereas, poultry manure from Canada are collected from the poultry houses almost on a daily basis. This could be the reason for high $\mathrm{N}$ content of PMC as the manure has not been exposed to the atmosphere for a long time. Saw dust was added to the PMN which would have added bulk and carbon to the manure hence rendered nitrogen non-available. The formula used to estimate available $\mathrm{N}$ might not be appropriate for PMN due to immobilization of $\mathrm{N}$ by the added saw dust often used for bedding which adds bulk and carbon.

\subsection{Effects of Nitrogen Source and Rates of Application on $\mathbf{N}$ and $P$ Uptake, and Shoot Biomass of Amaranth Plant in the Red River Clay}

Table 4 shows the effects of $\mathrm{N}$ source and rate of $\mathrm{N}$ on nutrient uptake and plant shoot biomass of amaranth in the Red River and Glenhope soils. In the Red River soil, there was a significant effect of $\mathrm{N}$ source $(\mathrm{p}<0.001)$ and $\mathrm{N}$ rate $(\mathrm{p}<$ $0.0065)$ on the nitrogen uptake of amaranth but the source by rate interaction was not significant ( $p>0.05$, Table 4). The lack of a significant interaction between source and rate allows us to look at the main effects of source and rate on

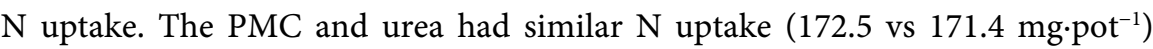
both of which were significantly greater than the N uptake from PMN (100.6 $\mathrm{mg} \cdot$ pot $\left.^{-1}\right)$. Many of the previous studies in Nigeria on the effect of poultry manure on vegetables focused only on yield with limited information on nutrient uptake. For example, the works of [36] on the growth and yield of tomato (Lycopersicon esculentum mill) as influenced by poultry manure and NPK fertilizer, [37] on the integrated application of poultry manure and NPK fertilizer on performance of tomato in derived savanna transition zone of Southwestern Nigeria, [38] on the effects of organic, organomineral and NPK fertilizer on nutritional 
Table 4. Effects of source and rate of nitrogen on nitrogen and phosphorus uptake, and shoot biomass yield of vegetable amaranth.

\begin{tabular}{|c|c|c|c|c|c|c|c|c|c|}
\hline \multirow{3}{*}{ Fertilizer types } & \multirow{3}{*}{ Rate } & & \multicolumn{3}{|c|}{ Red river clay } & \multicolumn{4}{|c|}{ Glenhope loamy sand } \\
\hline & & & $\mathrm{N}$ & $\mathrm{P}$ & BY & & $\mathrm{N}$ & $\mathrm{P}$ & BY \\
\hline & & & \multicolumn{2}{|c|}{$\mathrm{mg} \cdot \operatorname{pot}^{-1}$} & \multicolumn{2}{|l|}{ g.pot ${ }^{-1}$} & \multicolumn{2}{|c|}{$\mathrm{mg} \cdot \operatorname{pot}^{-1}$} & $\mathrm{~g} \cdot \operatorname{pot}^{-1}$ \\
\hline CONT & 0 & & 92.2 & 35.3 & 7.3 & & 96.7 & 12.6 & 5.4 \\
\hline PMC & 60 & & 167.6 & 41.6 & 9.9 & & 144.8 & 25.1 & 7.7 \\
\hline PMC & 120 & & 177.4 & 45.6 & 10.4 & & 194.2 & 30.8 & 9.8 \\
\hline $\mathrm{PMN}$ & 60 & & 104.0 & 37.9 & 6.6 & & 112.0 & 24.9 & 6.5 \\
\hline PMN & 120 & & 97.24 & 42.0 & 6.8 & & 108.0 & 31.2 & 6.2 \\
\hline UREA & 60 & & 150.6 & 34.5 & 8.7 & & 141.9 & 11.2 & 7.6 \\
\hline UREA & 120 & & 192.2 & 34.4 & 10.4 & & 185.4 & 11.6 & 8.6 \\
\hline SE & & & 13.29 & 4.22 & 0.69 & & 12.1 & 1.60 & 0.6 \\
\hline \multicolumn{10}{|l|}{ Source effect } \\
\hline PMC & & & 172.5 & $43.6 \mathrm{a}$ & $10.1 \mathrm{a}$ & & $169.5 \mathrm{a}$ & $27.9 \mathrm{a}$ & $8.8 \mathrm{a}$ \\
\hline PMN & & & $100.6 \mathrm{~b}$ & $40.0 \mathrm{ab}$ & $6.7 \mathrm{~b}$ & & $110.0 \mathrm{~b}$ & $28.1 \mathrm{a}$ & $6.4 \mathrm{~b}$ \\
\hline UREA & & & $171.4 \mathrm{a}$ & $34.5 b$ & $9.6 \mathrm{a}$ & & $163.7 \mathrm{a}$ & $11.4 \mathrm{~b}$ & $8.1 \mathrm{a}$ \\
\hline SE & & & 10.50 & 2.79 & 0.48 & & 9.51 & 1.37 & 0.45 \\
\hline \multicolumn{10}{|l|}{ Rate effect } \\
\hline 0 & & & $92.2 \mathrm{~b}$ & $35.3 \mathrm{~b}$ & $7.3 \mathrm{~b}$ & & $96.7 \mathrm{c}$ & $12.6 \mathrm{~b}$ & $5.4 \mathrm{~b}$ \\
\hline 60 & & & $140.7 \mathrm{a}$ & $38.0 \mathrm{ab}$ & $8.4 \mathrm{a}$ & & $132.9 \mathrm{~b}$ & $20.4 \mathrm{a}$ & $7.3 \mathrm{a}$ \\
\hline 120 & & & $155.6 \mathrm{a}$ & $40.7 \mathrm{a}$ & $9.2 \mathrm{a}$ & & $162.6 \mathrm{a}$ & $24.5 \mathrm{a}$ & $8.2 \mathrm{a}$ \\
\hline SE & & & 13.10 & 2.68 & 0.52 & & 9.42 & 2.23 & 0.45 \\
\hline Model effect & & d.f. & & $\mathrm{p}$ value & & d.f. & & $\mathrm{p}$ value & \\
\hline N Source & & 2 & $<0.0001$ & 0.1569 & $<0.0001$ & 2 & $<0.0001$ & 0.0001 & $<0.0001$ \\
\hline N Rate & & 2 & 0.0065 & 0.4011 & 0.0789 & 2 & 0.0008 & 0.0078 & 0.0009 \\
\hline Source $\times$ Rate & & 4 & 0.3383 & 0.8798 & 0.5667 & 4 & 0.0764 & 0.2441 & 0.1978 \\
\hline
\end{tabular}

quality of amaranthus in Lagos, [39] on the evaluation of some manure types for the growth and yield of water melon in Southwestern Nigeria and [17] on the effect of NPK and poultry manure on growth, yield and proximate composition of three amaranths did not consider the effects of poultry manure on nutrient uptake.

We are also not aware of previous studies that poultry manure from Nigeria was collected with some saw dust with possibly higher C:N ratio than that of PMC. [40] reported C/N ratio of 400:1 for sawdust. The greater amount of carbon in the PMN could have brought about $\mathrm{N}$ immobilization, therefore, rendering $\mathrm{N}$ non-available to the plant. This is supported by the earlier work of [41] who compared the effects of the two types of poultry manures (poultry manure from Canada and Nigeria) on $\mathrm{N}$ availability and uptake by amaranth plant. Re- 
sults of manure analyses showed that the total $\mathrm{N}$ content of PMC was $6.9 \%$ while that of PMN was $2.3 \%$ (Table 3). However, the two manures were applied to supply the same amount of nitrogen per pot $\left(67 \mathrm{mg} \mathrm{N} \cdot\right.$ pot $^{-1}$ for the $60 \mathrm{~kg} \cdot \mathrm{N} \cdot \mathrm{ha}^{-1}$ rate) and (133 $\mathrm{mg} \mathrm{N} \mathrm{pot}^{-1}$ for the $120 \mathrm{~kg} \cdot \mathrm{N} \cdot \mathrm{ha}{ }^{-1}$ rate).

The greater amount of carbon in the PMN could have brought about $\mathrm{N}$ immobilization rendering $\mathrm{N}$ non-available to the plant. This is supported by the earlier work of [42] who observed that high $\mathrm{C}$ relative to $\mathrm{N}$ would lead to a tie-up of $\mathrm{N}$, potentially causing $\mathrm{N}$ deficiency in the crop and a $\mathrm{C} / \mathrm{N}$ ratio of $25 / 1$ or greater would lead to $\mathrm{N}$ tie-up in the soil. Also the expression for estimating available $\mathrm{N}$, (Available $\mathrm{N}=\mathrm{NH}_{4}^{+}+25 \%$ of Organic $\mathrm{N}$ ), may be appropriate for PMC but not for PMN. The two rates of $\mathrm{N}\left(60\right.$ and $\left.120 \mathrm{~kg} \cdot \mathrm{N} \cdot \mathrm{ha}^{-1}\right)$ had similar N uptake (140.7 vs $155.6 \mathrm{mg} \cdot$ pot $^{-1}$ ), both of which were significantly greater than that of the control $\left(92.2 \mathrm{mg} \cdot \mathrm{pot}^{-1}\right)$. This result indicates that the application of poultry manure increased $\mathrm{N}$ uptake, however, the $60 \mathrm{~kg} \cdot \mathrm{N} \cdot \mathrm{ha}{ }^{-1}$ appeared to be the optimal rate in this soil beyond which there was no further increase in $\mathrm{N}$ uptake. This supports the findings of [43] who obtained significant increase in nutrient uptake of sokoyokoto (Celosia argentea), especially N, P and $\mathrm{K}$ with increasing rates of $\mathrm{N}$ fertilizer in which the optimum nutrient uptake was at 30 $\mathrm{kg} \cdot \mathrm{N} \cdot \mathrm{ha}{ }^{-1}$ with a decline in nutrient uptake at $40 \mathrm{~kg} \cdot \mathrm{N} \cdot \mathrm{ha}{ }^{-1}$. Interaction of $\mathrm{N}$ source and rate had no significant effect on shoot dry matter yield however, the yield was significantly higher for the plants that received PMC and urea compared with PMN.

Similar shoot dry matter yield (10.1 vs. $9.6 \mathrm{mg} \cdot$ pot $^{-1}$ ) was obtained with the application of PMC and urea to Red River soil both of which were significantly greater than that of PMN (6.7 mg.pot $\left.{ }^{-1}\right)$. The greater amaranth shoot dry matter yield from PMC and urea was due to greater uptake of $\mathrm{N}$ from these two sources of $\mathrm{N}$ compared to that of PMN. This corroborates the findings of [17] who reported an increase in the dry matter yield of Amaranthus cruentus with the application of poultry manure and NPK, [44] also reported an increase in the dry matter yield of potato with the application of supplemental poultry manure at the rate of 0 and $4 \mathrm{Mg} \mathrm{ha}^{-1}$ with the highest value recorded at $4 \mathrm{Mg} \mathrm{ha}^{-1}$, and [45] observed a linear increase in the biomass yield of two-year-old Saskatoon plants of the cultivar smoky with the application of 20-20-20 N- $\mathrm{P}_{2} \mathrm{O}_{5}-\mathrm{K}_{2} \mathrm{O}$ at the rate of $30,60,90$, and $120 \mathrm{~kg} \cdot \mathrm{N} \cdot \mathrm{ha}^{-1}$ with the highest value recorded at 120 $\mathrm{kg} \cdot \mathrm{N} \cdot \mathrm{ha}^{-1}$. Shoot dry matter yield was similar at application of $60 \mathrm{~kg} \cdot \mathrm{N} \cdot \mathrm{ha}^{-1}$ and $120 \mathrm{~kg} \cdot \mathrm{N} \cdot \mathrm{ha}^{-1}$ compared to control. Earlier works by [46] showed positive response of amaranth to $\mathrm{N}$ application. [47] observed an increase in shoot dry matter yield of vegetable amaranth with the application of $45 \mathrm{~kg} \cdot \mathrm{N} \cdot \mathrm{ha}^{-1}$ nitrogen fertilizer. [48] reported increasing yield response of Amaranthus cultivars at 40 $\mathrm{kg} \cdot \mathrm{N} \cdot \mathrm{ha}^{-1}$ poultry manure. [49] obtained an increase in plant height and number of leaves of Amaranthus cruentus at increasing household solid organic waste tea nitrogen rates from $60 \mathrm{~kg} \cdot \mathrm{N} \cdot \mathrm{ha} \mathrm{a}^{-1}$ up to $120 \mathrm{~kg} \cdot \mathrm{N} \cdot \mathrm{ha}^{-1}$ with a significant decrease at $160 \mathrm{~kg} \cdot \mathrm{N} \cdot \mathrm{ha}^{-1}$. 


\subsection{Effects of Nitrogen Source and Rates of Application on $\mathbf{N}$ and $P$ Uptake, and Shoot Biomass of Amaranth Plant in the Glenhope Loamy Sand}

In the Glenhope soil, no significant source-by-rate effect was found for any of the parameters which were similar to the situation in Red River soil (Table 4). This allowed us to focus on the main effects. A significant effect of $\mathrm{N}$ source $(\mathrm{p}<$ $0.0001)$ and $\mathrm{N}$ rate $(\mathrm{p}<0.0008)$ on nitrogen uptake of amaranth was obtained. The plant grown in soil treated with PMC and Urea had similar N uptake (169.5 vs $163.7 \mathrm{mg} \cdot$ pot $\left.^{-1}\right)$ both of which were significantly greater than the $\mathrm{N}$ uptake from PMN (110.0 mg.pot ${ }^{-1}$ ). The impacts of the two rates of $\mathrm{N}$ (60 and 120 $\left.\mathrm{kg} \cdot \mathrm{N} \cdot \mathrm{ha}^{-1}\right)$ showed that $120 \mathrm{~kg} \cdot \mathrm{N} \cdot \mathrm{ha}^{-1}$ produced significant higher $\mathrm{N}$ uptake $\left(162.6 \mathrm{mg} \cdot \mathrm{pot}^{-1}\right)$ compared to $60 \mathrm{~kg} \cdot \mathrm{N} \cdot \mathrm{ha}^{-1}\left(132.9 \mathrm{mg} \cdot \mathrm{pot}^{-1}\right)$, both of which were significantly greater than that of the control $\left(96.7 \mathrm{mg} \cdot \mathrm{pot}^{-1}\right)$. These results ascertained the earlier observation in the Red River soil that $\mathrm{N}$ availability from PMC and Urea were higher than that of PMN and the nutrient uptake increased with the increase in $\mathrm{N}$ application rates.

Unlike in the Red River soil where no significant effects of $\mathrm{N}$ source or rate on the uptake of $\mathrm{P}$ by Amaranth as a result of the high available $\mathrm{P}$ in this soil (Table 2), treatment effects on $P$ uptake were significant in the less fertile Glenhope soil. Phosphorus uptakes from PMC (27.9 mg.pot $\left.{ }^{-1}\right)$ and PMN (28.1 mg.pot ${ }^{-1}$ ) were similar and both were significantly $(\mathrm{p}<0.0001)$ higher than the $\mathrm{P}$ uptake from urea (11.4 mg.pot $\left.{ }^{-1}\right)$. This result showed that PMC and PMN contained similar amounts of available $\mathrm{P}$ which was not surprising considering the similar concentration of $P$ in both sources of manure (Table 3). [37] reported an increase in $\mathrm{P}$ uptake of tomato with poultry manure application. The $\mathrm{P}$ uptake at 60 and 120 $\mathrm{kg} \cdot \mathrm{N} \cdot \mathrm{ha}^{-1}$ (20.4 vs $24.5 \mathrm{mg} \cdot \mathrm{pot}^{-1}$ ) were similar, both of which were significantly higher than the P uptake form the control (12.6 mg.pot ${ }^{-1}$ ). Previous studies have reported that the stimulating effect of nitrogen on phosphorus uptake by plants may be attributable to increased root proliferation resulting from nitrogen application [50], changes in the availability of soil phosphorus due to chemical and acidity changes in the rhizosphere [51] and nitrogen stimulated physiological changes within the plant itself that influence phosphorus transport [52]. There was no significant $\mathrm{N}$ source by $\mathrm{N}$ rate interaction on amaranth shoot biomass yield in the Glenhope soil.

The main treatment effects on shoot biomass showed similar patterns to those observed for $\mathrm{N}$ and P uptake; the application of PMC and Urea produced similar

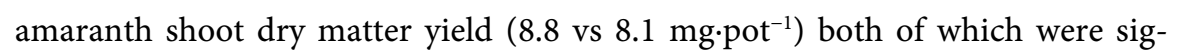
nificantly $(\mathrm{p}<0.0001)$ higher than that of the PMN $\left(6.4 \mathrm{mg} \cdot \mathrm{pot}^{-1}\right)$. This result was also observed in the Red River soil, where the higher amaranth shoot dry matter yield obtained could be attributed to greater uptake of nitrogen from the poultry manures. This corroborated the findings of [17] who reported an increase in shoot dry matter yield of Amaranthus cruentus with the application of poultry manure and NPK. The impact of the two rates of N (60 and 120 $\mathrm{kg} \cdot \mathrm{N} \cdot \mathrm{ha}^{-1}$ ) on the dry mater yield of amaranth were similar; both rates produced 
significantly $(\mathrm{p}<0.0009)$ greater shoot dry mater yield DMY than the control $\left(5.4 \mathrm{mg} \cdot \mathrm{pot}^{-1}\right)$. These results showed that increase in $\mathrm{N}$ uptake at $120 \mathrm{~kg} \cdot \mathrm{N} \cdot \mathrm{ha}^{-1}$ did not result in an increase in amaranth shoot dry mater yield. A similar result was obtained by [37] who applied 0, 15, 3045 and $60 \mathrm{~kg} \cdot \mathrm{N} \cdot \mathrm{ha} \mathrm{a}^{-1}$ of nitrogen fertilizer to Amaranthus cruentus where the shoot dry matter yield was not significantly different between the 45 and $60 \mathrm{~kg} \cdot \mathrm{N} \cdot \mathrm{ha}^{-1}$.

\subsection{Effects of Nitrogen Source and Rates of Application on $\mathrm{K}$, Ca and Mg Uptake of Amaranth Plant in the Red River Clay}

Table 5 shows the effects of $\mathrm{N}$ source and rate of $\mathrm{N}$ on $\mathrm{K}, \mathrm{Ca}$ and $\mathrm{Mg}$ uptake of amaranth in Red River soil. There was no significant source by rate effect on the uptake of $\mathrm{K}$ and $\mathrm{Mg}$ but the interaction effect on $\mathrm{Ca}$ uptake was significant. The source by rate effect of PMC and Urea (156.1 vs $157.0 \mathrm{mg} \cdot$ pot $^{-1}$ ) on Ca uptake at $120 \mathrm{~kg} \cdot \mathrm{N} \cdot \mathrm{ha}^{-1}$ was significantly $(\mathrm{p}<0.0091)$ higher than the value of PMN (84.6 $\mathrm{mg} \cdot$ pot $^{-1}$ ) and control $\left(92.9 \mathrm{mg} \cdot\right.$ pot $\left.^{-1}\right)$. It might due to the effect of biomass yield. The uptake of $\mathrm{K}$ and $\mathrm{Ca}$ from PMC was significantly greater than that from Urea which was in turn significantly greater than that from PMN. It appeared that PMC supplied additional $\mathrm{K}$ and possibly $\mathrm{Ca}$ to amaranth while the differences in uptake of these nutrient elements influenced by the different $\mathrm{N}$ sources were related to differences in biomasss yield. No significant difference was found in the uptake of Mg between PMC and Urea indicating that this nutrient was not supplied by the manure, this might due to the fact that the soil already contained $\mathrm{Mg}$ to meet the needs of the plants and so any available $\mathrm{Mg}$ from the manure was not taken up by the plants.

However, the Mg uptake from PMC and urea were significantly greater than from PMN reflecting differences in biomass yield. The trend of $\mathrm{K}$ and Ca uptake was similar to that of nitrogen uptake, possibly due to the involvement of $\mathrm{K}$ in nitrogen metabolism by plant. For instance, [53] reported that $\mathrm{K}^{+}$is the dominant cation for counter balancing immobile anion in the cytoplasm, the chloroplast, and quite often also for mobile anions in the vacuoles, the xylem and phloem. Potassium influences the uptake and utilisation of $\mathrm{N}$ in plants because $\mathrm{K}$ is involved in translocation of carbohydrate produced through the photosynthesis to the sink where the carbohydrates joins with amino group to from protein. Our results corroborate the findings of [54] who reported increases in $\mathrm{K}$ and $\mathrm{Ca}$ uptake of maize with the application of poultry manure. The two rates of $\mathrm{N}$ (60 and $120 \mathrm{~kg} \cdot \mathrm{N} \cdot \mathrm{ha}{ }^{-1}$ ) had similar K uptake (430.1 vs $467.8 \mathrm{mg} \cdot \mathrm{pot}^{-1}$ ) and similar Ca uptake (128.9 vs $132.6 \mathrm{mg} \cdot$ pot $^{-1}$ ) both of which were significantly greater than that of the control (339.3 mg.pot $\left.{ }^{-1}\right)$ and $\left(92.9 \mathrm{mg} \cdot \mathrm{pot}^{-1}\right)$ for $\mathrm{K}$ and Ca uptake, respectively. This result indicated that the application of poultry manure increased $\mathrm{K}$ and Ca uptake, however, the rate of $60 \mathrm{~kg} \cdot \mathrm{N} \cdot \mathrm{ha} \mathrm{a}^{-1}$ gave the higher K and Ca uptake. Magnesium uptake from PMC and urea (60.5 vs 58.9 mg.pot $\left.{ }^{-1}\right)$ were similar and both were significantly $(\mathrm{p}<0.0001)$ higher than the Mg uptake from PMN (36.9 mg.pot ${ }^{-1}$ ).

The Mg uptake at 60 and $120 \mathrm{~kg} \cdot \mathrm{N} \cdot \mathrm{ha}^{-1}\left(49.0 \mathrm{vs} 55.2 \mathrm{mg} \cdot \mathrm{pot}^{-1}\right.$ ) were similar, 
Table 5. Effects of source and rate of nitrogen on $\mathrm{K}, \mathrm{Ca}$, and Mg uptake of vegetable amaranth.

\begin{tabular}{|c|c|c|c|c|c|c|c|c|c|}
\hline \multirow{3}{*}{ Fertilizer types } & \multirow{3}{*}{ Rate } & & \multicolumn{3}{|c|}{ Red river clay } & & \multicolumn{3}{|c|}{ Glenhope loamy sand } \\
\hline & & & $\mathrm{K}$ & $\mathrm{Ca}$ & $\mathrm{Mg}$ & & $\mathrm{K}$ & $\mathrm{Ca}$ & $\mathrm{Mg}$ \\
\hline & & & \multicolumn{3}{|c|}{$\mathrm{mg} \cdot \mathrm{pot}^{-1}$} & & \multicolumn{3}{|c|}{$\mathrm{mg} \cdot$ pot $^{-1}$} \\
\hline CONT & 0 & & 339.3 & 92.9 & 37.9 & & 198.8 & 93.0 & 39.0 \\
\hline PMC & 60 & & 525.6 & 143.3 & 57.9 & & 244.8 & 139.6 & 67.8 \\
\hline PMC & 120 & & 538.2 & 156.1 & 63.2 & & 298.0 & 169.6 & 84.4 \\
\hline PMN & 60 & & 342.4 & 119.3 & 37.8 & & 247.5 & 111.8 & 40.9 \\
\hline $\mathrm{PMN}$ & 120 & & 335.4 & 84.6 & 36.0 & & 253.9 & 114.5 & 38.6 \\
\hline UREA & 60 & & 422.2 & 124.0 & 51.4 & & 240.8 & 110.3 & 47.7 \\
\hline UREA & 120 & & 529.8 & 157.0 & 66.4 & & 236.0 & 128.8 & 71.0 \\
\hline SE & & & 40.24 & 12.25 & 6.10 & & 17.05 & 9.38 & 6.69 \\
\hline \multicolumn{10}{|l|}{ Source effect } \\
\hline PMC & & & $531.9 \mathrm{a}$ & $149.7 \mathrm{a}$ & $60.5 \mathrm{a}$ & & 271.4 & $154.6 \mathrm{a}$ & $76.1 \mathrm{a}$ \\
\hline $\mathrm{PMN}$ & & & $338.9 c$ & $102.0 \mathrm{c}$ & $36.9 b$ & & 250.7 & $113.2 \mathrm{~b}$ & $39.8 \mathrm{c}$ \\
\hline UREA & & & $476.0 \mathrm{~b}$ & $140.5 \mathrm{~b}$ & $58.9 \mathrm{a}$ & & 238.4 & $119.6 \mathrm{~b}$ & $59.4 \mathrm{~b}$ \\
\hline SE & & & 26.90 & 8.16 & 3.34 & & 17.40 & 7.61 & 4.81 \\
\hline \multicolumn{10}{|l|}{ Rate effect } \\
\hline 0 & & & $339.3 \mathrm{~b}$ & $92.9 \mathrm{~b}$ & $37.9 \mathrm{~b}$ & & $198.8 \mathrm{c}$ & $93.0 \mathrm{c}$ & $39.0 \mathrm{c}$ \\
\hline 60 & & & $430.1 \mathrm{a}$ & $128.9 \mathrm{a}$ & $49.0 \mathrm{a}$ & & $244.4 \mathrm{~b}$ & $120.6 \mathrm{~b}$ & $52.1 \mathrm{~b}$ \\
\hline 120 & & & $467.8 \mathrm{a}$ & $132.6 \mathrm{a}$ & $55.2 \mathrm{a}$ & & $262.6 \mathrm{a}$ & $137.6 \mathrm{a}$ & $64.7 \mathrm{a}$ \\
\hline SE & & & 29.37 & 7.87 & 3.62 & & 16.20 & 7.57 & 5.17 \\
\hline Model effect & & d.f. & & $\mathrm{p}$ value & & d.f. & & $p$ value & \\
\hline N Source & & 2 & $<0.0001$ & $<0.0001$ & $<0.0001$ & 2 & 0.0569 & $<0.0001$ & $<0.0001$ \\
\hline N Rate & & 2 & 0.0241 & 0.0078 & 0.0198 & 2 & 0.0315 & 0.0022 & 0.0132 \\
\hline Source $\mathrm{x}$ Rate & & 4 & 0.2927 & 0.0091 & 0.2192 & 4 & 0.5863 & 0.4611 & 0.1288 \\
\hline
\end{tabular}

both of which were significantly higher than the control (37.9 $\left.\mathrm{mg} \cdot \mathrm{pot}^{-1}\right)$. Magnesium uptake was significantly higher at 60 and $120 \mathrm{~kg} \cdot \mathrm{N} \cdot \mathrm{ha}^{-1}$ than at $0 \mathrm{~kg} \cdot \mathrm{N} \cdot \mathrm{ha} \mathrm{a}^{-1}$ (control) by $29.3 \%$ and $45.6 \%$, respectively. [53] reported that magnesium is a component of chlorophyll and is related to the function of nitrogen in plants. It is involved in the transfer of carboxyl groups from the leave to the root for the production of protein and magnesium is preferentially bound to nitrogen. The Ca uptake from the $120 \mathrm{~kg} \cdot \mathrm{N} \cdot \mathrm{ha}^{-1}$ of PMC was greater than that of the 60 $\mathrm{kg} \cdot \mathrm{N} \cdot \mathrm{ha}^{-1}$, while for PMN Ca uptake at the $120 \mathrm{~kg} \cdot \mathrm{N} \cdot \mathrm{ha}^{-1}$ was less than at the 60 $\mathrm{kg} \cdot \mathrm{N} \cdot \mathrm{ha}^{-1}$, leading to the significant source by rate interaction for $\mathrm{Ca}$ (Table 5).

\subsection{Effects of Nitrogen Source and Rates of Application on $\mathrm{K}$, Ca and Mg Uptake of Amaranth Plant in the Glenhope Loamy Sand}

In the Glenhope soil, there was no significant source by rate effect on any of the 
parameters allowing us to focus on the main effects (Table 5). There was no significant effect of $\mathrm{N}$ source while a significant effect of $\mathrm{N}$ rate $(\mathrm{p}<0.0315)$ was obtained for $\mathrm{K}$ uptake in the Glenhope soil. The $120 \mathrm{~kg} \cdot \mathrm{N} \cdot \mathrm{ha}^{-1}$ rate produced significant higher $\mathrm{K}$ uptake $\left(262.6 \mathrm{mg} \cdot \mathrm{pot}^{-1}\right)$ compared to the $60 \mathrm{~kg} \cdot \mathrm{N} \cdot \mathrm{ha}^{-1}(244.4$ $\left.\mathrm{mg} \cdot \operatorname{pot}^{-1}\right)$, both of which were significantly greater than that of the control (198.8 mg.pot $\left.{ }^{-1}\right)$. Calcium uptake from PMC (154.6 mg.pot $\left.{ }^{-1}\right)$ was significantly greater than Ca uptake from urea (119.6 mg.pot $\left.{ }^{-1}\right)$ and PMN (113.2 mg.pot $\left.{ }^{-1}\right)$ but both of which were not significantly different from each other. The 120 $\mathrm{kg} \cdot \mathrm{N} \cdot \mathrm{ha}^{-1}$ rate produced significantly higher Ca uptake (137.6 mg.pot $\left.{ }^{-1}\right)$ compared to $60 \mathrm{~kg} \cdot \mathrm{N} \cdot \mathrm{ha}^{-1}\left(120.6 \mathrm{mg} \cdot \mathrm{pot}^{-1}\right)$, both of which were significantly greater than that of the control $\left(93.0 \mathrm{mg} \cdot\right.$ pot $\left.^{-1}\right)$. Calcium uptake was significantly higher at 60 and $120 \mathrm{~kg} \cdot \mathrm{N} \cdot \mathrm{ha}^{-1}$ than at $0 \mathrm{~kg} \cdot \mathrm{N} \cdot \mathrm{ha}^{-1}$ (control) by $29.68 \%$ and $47.96 \%$, respectively in Glenhope soil. This may be due to the high concentration of $\mathrm{Ca}$ in poultry manure used for the experiment (Table 3 ). This is in line with the work of [55] who reported that Farm yard manure supplies all major nutrients (N, P, $\mathrm{K}, \mathrm{Ca}, \mathrm{Mg}$ and S) necessary for plant growth.

The PMC had the highest Mg uptake (76.1 $\mathrm{mg}$.pot $^{-1}$ ) followed by Mg uptake from Urea $\left(59.4 \mathrm{mg} \cdot \mathrm{pot}^{-1}\right.$ ) both of which were significantly greater than the $\mathrm{Mg}$ uptake from PMN (39.8 mg. pot $\left.^{-1}\right)$. Considering the impact of the two rates, the $\mathrm{Mg}$ uptake at $120 \mathrm{~kg} \cdot \mathrm{N} \cdot \mathrm{ha}^{-1}\left(64.7 \mathrm{mg} \cdot \mathrm{pot}^{-1}\right)$ was significantly higher than $\mathrm{Mg}$ uptake at $60 \mathrm{~kg} \cdot \mathrm{N} \cdot \mathrm{ha}^{-1}\left(52.1 \mathrm{mg} \cdot \mathrm{pot}^{-1}\right)$, both of which were significantly higher than the control $\left(39.0 \mathrm{mg} \cdot \mathrm{pot}^{-1}\right)$. The results of $\mathrm{N}$ and $\mathrm{P}$ uptake as well as biomass yield of amaranth were consistent for the two soils used in this study. [56] reported that vertisols are very high in swelling-clays and had the highest average CEC of the mineral soils which could be the reason for the higher $\mathrm{K}$ uptake in the Red River soil with a CEC of $46.8 \mathrm{cmol} \cdot \mathrm{kg}^{-1}$ compared with the Glenhope soil with a CEC of $19 \mathrm{cmol} \cdot \mathrm{kg}^{-1}$ in the current study. For $\mathrm{N}$ rate at 60 $\mathrm{kg} \cdot \mathrm{N} \cdot \mathrm{ha}^{-1}$ and $120 \mathrm{~kg} \cdot \mathrm{N} \cdot \mathrm{ha}^{-1}$ a significant difference in value was obtained in Glenhope soil but not in the Red River soil reflecting a better fertility of the Red River soils.

\section{Conclusion}

The effects of these two types of poultry manure (from Nigeria and Canada) and urea fertilizer on biomass yield and nutrient uptake of vegetable amaranth were investigated in the greenhouse. Poultry manure from Canada and urea promoted nitrogen uptake and biomass yield more than poultry manure from Nigeria. Nitrogen uptake from the two rates of the manures was significantly greater than that of the (control) non-amended. Poultry manure from Canada was superior to poultry manure from Nigerian considering nitrogen uptake from the manure. Poultry manure from Nigeria would be a good source of $\mathrm{P}$ for plant growth since most Nigeria soils are low in P. The study showed that the formula for estimating available nitrogen from poultry manure was more appropriate for PMC than PMN, possibly due to the use of 
saw dust in poultry houses in Nigeria.

\section{Acknowledgements}

The Authors appreciated the fund (Graduate Student's Exchange Programme Grant) provided by the Canadian Bureau for International Education (CBIE) in collaboration with the Department of Foreign Affairs and International Trade Canada (DFAIT), for the first author to carry out the study at the University of Manitoba, Winnipeg, Manitoba, Canada and Mrs. Bammeke of the Department of Soil Science, of the University for the technical assistance rendered. This manuscript was part of the M. Phil. Research of the first author which was awarded by the Obafemi Awolowo Univeristy, Ile-Ife, Nigeria.

\section{Conflicts of Interest}

The authors declare no conflicts of interest regarding the publication of this paper.

\section{References}

[1] Food and Agricultural Organization (2014) The State of Food Insecurity in the World. FAOSTAT, Rome.

[2] Agwe, J., Morris, M. and Fernandes, E. (2007) Africa's Growing Soil Fertility Crisis: What Role for Fertilizer? Agricultural and Rural Development Notes. http://openknowledge.worldbank.org/handle/10986/9573

[3] Omotayo, O.E. and Chukwuka, K.S. (2009) Soil Fertility Restoration Techniques in Sub-Saharan Africa Using Organic Resources. African Journal of Agricultural Research, 4, 144-150.

[4] Bationo, A. (2009) The Proceedings of International Plant Nutrition Colloquium XVI. 8th February 2008.

[5] Adesanwo, O.O., Adetunji, M.T., Adesanwo, J.K., Osiname, O.A., Diatta, S. and Torimiro, D.O. (2009) Evaluation of Traditional Soil Fertility Management Practices for Rice Cultivatio $\mathrm{n}$ in South-Western Nigeria. American-Eurasian Journal of Agronomy, 2, 45-49.

[6] Erkossa, T., Awulachew, S.B. and Aster, D. (2011) Soil Fertility Effect on Water Productivity of Maize in the Upper Blue Nile Basin, Ethiopia. Agricultural Science, 2, 238-247. https://doi.org/10.4236/as.2011.23032

[7] Idowu M.K., Oyedele, D.J. and Oladele, A.O. (2017) Influence of Nitrogen Fertilizer Application on Organic Carbon Content of Underutilized Vegetable Grown Soils in Southwestern Nigeria. Global Symposium on Soil Organic Carbon, Rome, 21-23 March 2017, 4 p.

[8] Salami, B.T. and Sangoyomi, T.E. (2013) Soil Fertility Status of Cassava Fields in Southwestern Nigeria. American Journal of Experimental Agriculture, 3, 152-164. https://doi.org/10.9734/AJEA/2013/2088

[9] Olayinka, A. and Adebayo, A. (1984) Effects of Incubation Temperature and Different Sources of N and P on Decomposition of Sawdust in Soil. Agricultural Waste, 2, 293-306. https://doi.org/10.1016/0141-4607(84)90037-4

[10] Idowu, M.K. (2005) The Effects of Sodium and Potassium on Growth, Yield, Nutrient Content and Nutritional Quality of Tomato (Lycopersicum lycopersicum L.) 
Karst. PhD Thesis, 1-2.

[11] Mufwanzala, N. and Dikinya, O. (2010) Impact of Poultry Manure and Its Associated Salinity on the Growth and Yield of Spinach (Spinacea oleracea) and Carrot (Daucus carota). International Journal of Agriculture \& Biology, 12, 489-494.

[12] Rahman, S.A. (2004) The Place of Organic Manure in Sustaining Agricultural Development in Nigeria. Science Technology and Society National Workshop, Lafia, 11 July 2004.

[13] Idowu, M.K., Manning, D.A.C. and Borland, A.M. (2013) Soil Potassium and Sodium, Physiological Responses and Yields of Tomato as Affected by Potassium Feldspar in Soil Culture. Ife Journal of Agriculture, 26, 1-7.

[14] Olayinka, A. and Ailenubhi, V. (2003) Microbial Respiration, Maize (Zeamays L.) Growth and Nitrogen Uptake as Affected by Cowdung and Ammonium Sulphate Application. Nigeria Journal of Soil Research, 4, 16-24. https://doi.org/10.4314/njser.v4i1.28378

[15] Idowu, M.K. (2008) Does Gender Affect the Quality of Soil and Vegetable Amaranth under Peri-Urban of Osun State. Nigerian Agricultural Journal, 40, 312-320. https://doi.org/10.4314/naj.v40i1-2.55603

[16] Shadi, A., William, P.M., Miguel, L.C. and Sayed, M.H. (2011) Arsenic in Soils and Forages from Poultry Litter Amended Pasture. International Journal of Environmental Research Public Health, 8, 1534-1546. https://doi.org/10.3390/ijerph8051534

[17] Oyedeji, S., Animasaun, D.A., Bello, A.A. and Agboola, O.O. (2014) Effect of NPK and Poultry Manure on Growth, Yield, and Proximate Composition of Three Amaranths. Journal of Botany, 2014, Article ID: 828750.

https://doi.org/10.1155/2014/828750

[18] Neil, G. (2007) Best Practice Guidelines for Using Poultry Litter on Pastures. Benchmark House, Sheffield, 3-4.

[19] Jeanna, L.W. (2012) Land Application of Livestock and Poultry Manure. The University of Georgia and Ft. Valley State University, the U.S. Department of Agriculture and Counties of the State Cooperating, Athens, $3 \mathrm{p}$.

[20] Aina, P.O. (1981) The Effect of Soil Amendment with Poultry Manure on the Elemental Composition of Maize (Zeamays). Beitrage zur Tropischen Landwirtschaft und Veterinarmedizin, 19, 173-177.

[21] Ige, D.V., Adepetu, J.A., Obi, O.A. and Adetunji, M.T. (2004) Phosphate Sorption Potential as a Predictor of Plant Available Phosphate in Soils of Southwestern Nigeria.

[22] Ebert, A.W., Wu, T. and Wang, S. (2011) International Cooperators' Guide: Vegetable Amaranth (Amaranthus L.). AVRDC Publication No. 11-754. Asian Vegetable Research and Development Center, Shanhua.

[23] Food Development Centre (2017) Growing Opportunities in Food. http://www.manitoba.ca/agriculture/fdc

[24] Umar, K.J., Hassan, L.G., Dangoggo, S.M., Maigandi, S.A. and Sani, N.A. (2011) Nutritional and Anti-Nutritional Profile of Spiny Amaranth (Amaranthus viridis Linn). Studia Universitatis “Vasile Goldiş”, Seria Ştiințele Vieții, 21, 727-737.

[25] Idowu, M.K., Oyedele, D.J., Adekunle, K.O., Akinremi, O.O. and Eilers, B. (2014) Effects of Planting Methods and Seed Density on Vegetable Yield and Nutrient Composition of Solanum macrocarpon and Solanum scabrum in Southwest Nigeria. Food and Nutrition Sciences, 5, 1185-1195.

https://doi.org/10.4236/fns.2014.513129 
[26] Manitoba Agriculture, Food and Rural Initiatives (2006) Pork in Manitoba. http://www.gov.mb.ca/agriculture/livestock/pork/bab01s00.html

[27] Cassel, D.K. and Nielsen, D.R. (1986) Field Capacity and Available Water Capacity. In: Methods of Soil Analysis Part 1, Agronomy Society of America, Madison, Chapter 36, 901-926.

[28] Olsen, S.R. and Sommer, L.E. (1982) Phosphorus. In: Page, A.L., Ed., Methods of Soil Analysis, Part 2, 2nd Edition, American Society of Agronomy, Madison, 403-430.

[29] Clesceri, L.S., Greenbert, A.E., Eaton, A.D. and Franson, M.A.H. (1998) Standard Methods for the Examination of Water and Wastewater. 20th Edition, American Public Health Association, Washington DC, 1325 p.

[30] Rob, E. (1995) Cation Exchange Capacity (CE) and the Exchangeable Cations. Laboratory Analysis Procedure, 34.

[31] Thomas, R.L., Sheard, R.W. and Moyer, J.R. (1967) Comparison of Conventional and Automated Procedures for Nitrogen, Phosphorus, and Potassium Analysis of Plant Material Using a Single Digestion. Agronomy Journal, 59, 240-243. https://doi.org/10.2134/agronj1967.00021962005900030010x

[32] Akinremi, O.O., Armisen, N., Kashem, M.A. and Janzen, H.H. (2003) Evaluation of Analytical Methods for Total P in Organic Amendments. Communications in Soil Science and Plant Analysis, 34, 2981-2991. https://doi.org/10.1081/CSS-120025220

[33] Manure Management Facts, Manitoba (2009) Calculating Manure Application Rates. The Prairie Province's Committee on Livestock Development and Manure Management, 2-4.

[34] SAS (2002-2003) SAS, 9.1 Version.

[35] Wolfe, J.E. and Lind, T.O. (2008) Influence of Suspended Red River on Phosphorus Uptake by Periphyton. Hydro Biological, 610, 211-222. https://doi.org/10.1007/s10750-008-9436-7

[36] Adekiya, A.O. and Agbede, T.M. (2009) Growth and Yield of Tomato (Lycopersicon esculentum Mill) as Influenced by Poultry Manure and NPK Fertilizer. Emir Journal of Food Agriculture, 21, 10-20. https://doi.org/10.9755/ejfa.v21i1.5154

[37] Ayeni, L.S., Omole, T.O., Adeleye, E.O. and Ojeniyi, S.O. (2010) Integrated Application of Poultry Manure and NPK Fertilizer on Performance of Tomato in Derived Savannah Transition Zone of Southwest Nigeria. Journal of American Science, 8, 50-54.

[38] Makinde, E.A., Ayeni, L.S., Ojeniyi, S.O. and Odedina, J.N. (2010) Effects of Organic, Organomineral and NPK Fertilizer on Nutritional Quality of Amaranthus in Lagos. Researcher, 2, 32-36.

[39] Okunlola, I.O., Adejoro, S.A. and Fakanlu, G. (2013) Evaluation of Some Manure Types for the Growth and Yield of Water melon in Southwestern Nigeria. Researcher, 3, 61-66.

[40] National Programme for Food Security Abuja Nigeria (2011) Compost Making and Use. A Guide for Crop Facilitators, Site Managers, Extension Agents and Farmers. 13-14.

[41] Carl, J.R. and Peter, M.B. (2005) Nutrient Management for Fruit and Vegetable Crop Production. Department of Soil, Water, and Climate, University of Minnesota Extension Bulletin, Minneapolis, $6 \mathrm{p}$.

[42] Olaniyi, J.O. and Ojetayo, A.E. (2012) Effects of Nitrogen on Growth, Yield, Nutrient Uptake and Quality of Celosia (Celosia argentea) Varieties. Journal of Agricul- 
ture and Biological Sciences, 3, 227-231.

[43] Rees, H.W., Chow, T.L., Zebarth, B.J., Xing, Z., Toner, P., Lavoie, J. and Daigle, J.L. (2011) Effects of Supplemental Poultry Manure Applications on Soil Erosion and Runoff Water Quality from a Loam Soil under Potato Production in Northwesternnew Brunswick. Canada Journal of Soil Science, 91, 595-613. https://doi.org/10.4141/cjss10093

[44] Zatylny, A.M. and St Pierre, R.G. (2006) Nitrogen Uptake, Leaf Nitrogen Concentration and Growth of Saskatoons in Response to Soil Nitrogen Fertility. Journal of Plant Nutrition, 29, 209-496. https://doi.org/10.1080/01904160500468738

[45] Showemimo, F.A. and Olarewaju, J.D. (2004) Growth Analysis, Protein and Yield of Vegetable Amaranth under Varying Nitrogen Fertilizer Levels and Contrasting Season. Nigerian Journal of Horticultural Science, 9, 33.

https://doi.org/10.4314/njhs.v9i1.3376

[46] Olaniyi, J.O., Adelasoye, K.A. and Jegede, C.O. (2008) Influence of Nitrogen Fertilizer on the Growth, Yield and Quality of Grain Amaranth Varieties. World Journal of Agricultural Sciences, 4, 506-513.

[47] Amadu, M.A. (2007) Response of Amaranthus Cultivars to Nitrogen Rates. International Journal of Scientific and Engineering Research, 4, 16-19.

[48] Idowu, M.K. and Odeyemi, B.O. (2013) Effects of Solid Household Organic Waste Tea Nitrogen on Seedling Emergence, Growth and Leaf Yield of Amaranthus cruentus and Celosia argentea in Ultisol. In: Proceedings of the 9 th National Conference on Organic Agriculture, Federal University of Agriculture, Abeokuta, 94-100.

[49] Grunes, D.L. (1959) Effect of Nitrogen on the Availability of Soil and Fertilizer Phosphorus to Plants. Advances in Agronomy, 2, 369-396. https://doi.org/10.1016/S0065-2113(08)60127-3

[50] Drew, M.C. and Saker, L.R. (1975) Nutrient Supply and the Growth of the Seminal Root System in Barely II Localised, Compensatory Increase in Lateral Root Growth and Rate of Nitrate Uptake When Nitrate Is Restricted to Only Part of the Root System. Journal of Experimental Botany, 26, 79-90. https://doi.org/10.1093/jxb/26.1.79

[51] Blair, G.J., Mamaril, C.P. and Miller, M.H. (1971) Influence of Nitrogen Source on Phosphorus Uptake by Corn from Soils Difference in pH. Agronomy Journal, 63, 235-238. https://doi.org/10.2134/agronj1971.00021962006300020012x

[52] Cole, C.V., Grumes, D.L., Porter, L.K. and Olsen, S.R. (1963) The Effect of Nitrogen on Short Term Phosphorus Absorption and Translocation in Corn (Zea mays). Soil Science Society of America, Proceedings, 27, 671-674. https://doi.org/10.2136/sssaj1963.03615995002700060031x

[53] Marschner, H. (1989) Mineral Nutrition of Higher Plants. 2nd Edition, Academic Press, London, 187-233.

[54] Ayeni, L.S., Adetunji, M.T., Ojeniyi, S.O., Ewulo, B.S. and Adeyemo, A.J. (2008) Comparative and Cumulative Effect of Cocoa Pod Husk Ash and Poultry Manure on Soil and Maize Nutrient Contents and Yield. American Eurasian Journal of Sustainable Agriculture, 2, 92-97.

[55] Tilahun, T., Nigussie, D., Wondimu, B. and Setegn, G. (2013) Effects of Farmyard Manure and Inorganic Fertilizer Application on Soil Physico Chemical Properties and Nutrient Balance in Rain-Fed Lowland Rice Ecosystem. American Journal of Plant Sciences, 4, 309-316. https://doi.org/10.4236/ajps.2013.42041

[56] Brady and Weil (1999) The Nature and Properties of Soil. 8th Edition, Prentice Hall, Upper Saddle River, 332-335. 


\section{Abbreviations}

PMC, poultry manure from Canada;

PMN, poultry manure from Nigeria;

CONT, control. 